\title{
Monitorowanie i ocena \\ systemów ubezpieczeń społecznych - przegląd kryteriów proponowanych przez Komisję Europejską i Bank Światowy oraz propozycje ich rozszerzenia w kontekście starzenia się populacji
}

\author{
Kamila Bielawska
}

\begin{abstract}
Abstrakt
Ubezpieczenia społeczne $\mathrm{w}$ wielu krajach są istotną częścią systemu zabezpieczenia społecznego. Specyficzne cechy ubezpieczeń społecznych, m.in. ekwiwalentność i roszczeniowość świadczeń czy odrębność źródeł finansowania, powodują, że należy dbać o to, aby interesariusze mieli stały dostęp do wiarygodnych informacji na ich temat, zarówno w zakresie stanu bieżącego, jak i w odpowiednio długim horyzoncie czasu. Powinno to sprzyjać zaufaniu do ubezpieczeń społecznych.

Celem artykułu jest dokonanie przeglądu obszarów i kryteriów stosowanych do oceny systemów ubezpieczeń społecznych na podstawie adaptacji rekomendacji Komisji Europejskiej oraz Banku Światowego w odniesieniu do systemów emerytalnych oraz wskazanie obszarów, których ocena powinna zyskać na znaczeniu w świetle starzenia się populacji.

Jak wynika z przeprowadzonej analizy, ocena adekwatności i stabilności finansowej jest rozwinięta i stanowi pewien standard. Natomiast obszar związany z modernizacją ubezpieczeń społecznych, tj. dostosowywaniem ich do zmieniającej się sytuacji demograficznej i ekonomicznej, jest nadal wyzwaniem. Zbyt małą rolę przypisuje się ocenie równości ze względu na płeć, skali redystrybucji, transparentności i wiarygodności informacji o ubezpieczeniach społecznych.
\end{abstract}

Słowa kluczowe: ocena, ubezpieczenia społeczne, wskaźniki.

Kamila Bielawska, dr, adiunkt w Katedrze Bankowości i Finansów, Wydział Zarządzania, Uniwersytet Gdański. 


\section{Wstęp}

Systemy zabezpieczenia społecznego w większości państw rozwiniętych stanowią istotne źródło transferów zastępujących lub/i uzupełniających dochód ludności w razie materializacji ryzyka społecznego. W wielu $\mathrm{z}$ tych systemów dominującą rolę odgrywa metoda ubezpieczenia, która na tle innych technik realizacji zabezpieczenia społecznego wyróżnia się specyficznymi cechami. Zgodnie z poglądami wielu autorytetów w badanym obszarze, które podziela autorka niniejszego opracowania, zastosowanie metody ubezpieczenia w systemach zabezpieczenia społecznego związane jest z koniecznością wprowadzenia pewnych odstępstw od klasycznych cech ubezpieczenia jako wyjątkowej metody postępowania z ryzykiem ${ }^{1}$. Rozwój ubezpieczeń społecznych i zaciągnięte w ich ramach zobowiązania wobec kolejnych pokoleń stają się coraz większym wyzwaniem w kontekście zmiany demograficznej i jej ekonomicznych konsekwencji. Również przemiany społeczno-kulturowe (zmiana wzorca rodziny, wzrost indywidualizmu, wzrost mobilności i form zarobkowania etc.) wymagają większego odzwierciedlenia w systemach ubezpieczeń społecznych.

Celem artykułu jest dokonanie przeglądu obszarów i wskaźników stosowanych do monitorowania i oceny systemów ubezpieczeń społecznych na podstawie rekomendacji Komisji Europejskiej i Banku Światowego oraz wskazanie obszarów, których ocena powinna być bardziej uwypuklona w świetle starzenia się populacji. $\mathrm{W}$ artykule zaimplementowano kryteria opisywane w literaturze przedmiotu jako służące do analizy systemów emerytalnych². Wiele $\mathrm{z}$ nich może mieć bezpośrednie zastosowanie do oceny systemów ubezpieczeń społecznych w odniesieniu do świadczeń długookresowych i krótkookresowych, co zostało zilustrowane przykładami i modyfikacją wybranych wskaźników.

1. Przegląd różnic w zasadach ubezpieczeniowych w odniesieniu do ubezpieczeń społecznych i prywatnych prezentowany w polskiej literaturze przedmiotu przedstawia m.in. M. Kawiński [w:] M. Kawiński, Ubezpieczenia publiczne i prywatne w polityce społecznej. Skuteczność i efektywność, Warszawa, Wydawnictwo C.H. Beck, 2011, s. 53 i nast. O różnicach w elementach ubezpieczeń społecznych na tle ubezpieczeń prywatnych również [w:] S. Golinowska, Polityka społeczna państwa w gospodarce rynkowej. Studium ekonomiczne, Warszawa, Wydawnictwo Naukowe PWN, 1994.

2. Por. T.H. Bednarczyk, K. Bielawska, B. Jackowska et al., Ekonomiczne i demograficzne uwarunkowania funkcjonowania i rozwoju ubezpieczeń, Gdańsk, Wydawnictwo Uniwersytetu Gdańskiego, 2019, s. $68-70$. 


\section{Cele funkcjonowania i kryteria oceny ubezpieczeń społecznych}

Ubezpieczenia społeczne są jedną z technik (metod) postępowania z ryzykiem społecznym, którego materializacja powoduje utratę (całkowitą lub częściową) możliwości zarobkowania. Z punktu widzenia osób utrzymujących się z pracy zależnej oznacza to utratę lub znaczące uszczuplenie głównego źródła utrzymania. Jest to istotny problem zwłaszcza dla tych społeczeństw, które nie osiągnęły jeszcze satysfakcjonującego statusu materialnego lub/i nie korzystają z prywatnych ubezpieczeń w tym zakresie ze względu na barierę dochodową, brak dostępności odpowiednich produktów ubezpieczeniowych czy też nieuświadomienie pewnych potrzeb (np. dostępu do opieki długoterminowej). Osoby narażone na określony rodzaj ryzyka społecznego (chorobę, wypadek przy pracy, utratę żywiciela rodziny, osiągnięcie wieku emerytalnego) z mocy prawa tworzą wspólnotę ubezpieczeniową, opłacają składki (składki mogą też być finansowane lub współfinansowane przez zatrudniających) do funduszu ubezpieczeniowego, a w przypadku materializacji ryzyka i po spełnieniu warunków otrzymują należne świadczenie, które powinno być powiązane $\mathrm{z}$ wkładem do systemu ${ }^{3}$.

Ze względu na mechanizm i zasady funkcjonowania, a także społeczny i ekonomiczny wymiar, system ubezpieczeń społecznych powinien podlegać monitoringowi zarówno bieżącemu, jak i długookresowemu pod kątem realizacji wyznaczonych celów.

Cele funkcjonowania systemu ubezpieczeń społecznych można rozpatrywać z punktu widzenia indywidualnego (uczestnika) oraz państwa jako inicjatora i prowadzącego ubezpieczenia społeczne. Z perspektywy uczestnika istotne jest, aby warunki dostępu do świadczeń (emerytury, renty, zasiłku chorobowego) oraz ich wysokość były akceptowane przez ubezpieczonego (świadczenia powinny w odpowiednim stopniu zastępować utracony przejściowo lub permanentnie dochód z pracy), a także by okres wypłaty świadczeń był dostosowany do skutków ryzyka (np. w ubezpieczeniu emerytalnym wypłata powinna być dożywotnia; przy innych świadczeniach należy poszukiwać odpowiedniej równowagi, tak aby zbyt długi okres pobierania świadczenia nie demotywował w kwestii powrotu na rynek pracy, jeśli jest on możliwy).

3. W języku polskim zarówno w odniesieniu do ubezpieczeń prywatnych, jak i społecznych używa się pojęcia „składka ubezpieczeniowa”, choć nie są to kategorie tożsame. Składka ubezpieczeniowa (ang. premium) oznacza ekwiwalent ochrony ubezpieczeniowej, podczas gdy składka w ubezpieczeniach społecznych jest bardziej formą wkładu pieniężnego (ang. contribution) do funduszu ubezpieczeniowego, którego kalkulacja nie uwzględnia ryzyka wnoszonego do wspólnoty ubezpieczeniowej. Ma to swoje konsekwencje również w odniesieniu do kalkulacji świadczeń. Szerzej o tych problemach por. T. Szumlicz, Ubezpieczenie. W sprawie zastrzeżenia terminologicznego, „Wiadomości Ubezpieczeniowe" 2009, $\mathrm{nr} 1$. 
Minimalne standardy zarówno w zakresie warunków dostępu do świadczeń, jak i ich relatywnej wysokości, bez względu na technikę realizacji zabezpieczenia społecznego, dla tzw. przeciętnego świadczeniobiorcy wyznacza Konwencja nr 102 Międzynarodowej Organizacji Pracy, którą Polska ratyfikowała w 2004 roku4 . Uczestnik systemu opłacając składki, ogranicza bieżącą konsumpcję po to, aby móc konsumować w okresie materializacji ryzyka społecznego, dlatego też w literaturze często ten cel jest określany jako wyrównywanie konsumpcji w cyklu życia ${ }^{5}$.

Do celów funkcjonowania systemów emerytalnych na poziomie organizatora systemu zalicza się najczęściej ochronę przed ubóstwem oraz redystrybucję dochodów ${ }^{6}$. Jednak, jak zaznacza Chybalski ${ }^{7}$, redystrybucja dochodów jest nie tyle celem w systemie emerytalnym, ile narzędziem, które służy do redukcji ubóstwa wśród emerytów. Cele te można również przypisać ubezpieczeniom społecznym, gdyż ich konstrukcja zazwyczaj jest tak ustalona, aby uczestnicy mieli możliwość osiągnięcia odpowiedniej wysokości świadczeń, oraz dopuszcza się w nich redystrybucję dochodów wykraczającą poza czynnik losowy. Jednocześnie zapewnienie minimalnej adekwatności świadczeń nie mogłoby być możliwe, gdyby system ubezpieczeń społecznych nie był stabilny finansowo w długim okresie. Realność ochrony ubezpieczeniowej w każdym systemie (publicznym czy prywatnym) powinna być zapewniona przez efektywną gospodarkę finansową oraz trwałość i wystarczalność źródeł finansowania.

Przed współczesnymi systemami stawia się również cele związane z adaptacją do zmieniających się uwarunkowań (demograficznych, ekonomicznych, społeczno-kulturowych). Podejście takie znajdujemy w dokumentach m.in. Komisji Europejskiej, która w 2003 roku opublikowała raport pt. „Adequate and Sustainable Pensions. Joint Report by the Commission and the Council”, w którym w ramach otwartej metody koordynacji (OMC) wskazano trzy obszary (cele) działań państw członkowskich w sferze zabezpieczenia emerytalnego: adekwatność (ang. adequacy), stabilność finansową (ang. sustainability) i modernizację (ang. modernisation). Polityka społeczna państw członkowskich Unii Europejskiej nie podlega harmonizacji, jednak wymaga koordynacji ze względu na podobieństwo wyzwań

4. Konwencja Nr 102 Międzynarodowej Organizacji Pracy dotycząca minimalnych norm zabezpieczenia społecznego, Dz. U. 2005 nr 93 poz. 775.

5. N. Barr, P. Diamond, Economic of pensions, „Oxford Review of Economic Policy” 2006, Vol. 22(1); N. Barr, Państwo dobrobytu jako skarbonka. Informacja, ryzyko, niepewność a rola państwa, Warszawa, Wydawnictwo Wyższej Szkoły Pedagogicznej TWP w Warszawie, 2010.

6. Por. N. Barr, P. Diamond, Economic of pensions, „Oxford Review of Economic Policy” 2006, Vol. 22(1).

7. F. Chybalski, Pomiar redystrybucji w międzynarodowych analizach systemów emerytalnych [w:] Wspótczesne problemy systemów emerytalnych. Wybrane zagadnienia, red. F. Chybalski i E. Marcinkiewicz, Monografie Politechniki Łódzkiej, Łódź 2015, s. 18.

8. European Commission, Adequate and Sustainable Pensions. Joint Report by the Commission and the Council, Luxemburg 2003. 
i konieczność wymiany informacji o bieżących i planowanych reformach ${ }^{9}$. Od tego czasu regularnie (co 3 lata) opracowywane są raporty dotyczące wpływu starzenia się ludności na sytuację budżetową państw członkowskich UE, raporty dotyczące adekwatności emerytur oraz stabilności fiskalnej z uwzględnieniem kosztów programów społecznych wrażliwych na zmianę demograficzną ${ }^{10}$. Warto wspomnieć, że ze względu na częste powiązanie w systemach ubezpieczeń społecznych emerytur i rent (rodzinnych czy z tytułu niezdolności do pracy) analizy przedstawiane w tych raportach odnoszą się łącznie do obu typów świadczeń długookresowych. Z kolei z punktu widzenia świadczeń krótkookresowych adekwatność jest istotna i może być tak samo oceniana jak przy emeryturach, natomiast stabilność finansową można monitorować na bieżąco przez pryzmat równowagi funduszu finansującego świadczenia (o ile jest odrębny od świadczeń długookresowych).

Wśród organizacji międzynarodowych również Bank Światowy uważa ochronę przed ubóstwem oraz wygładzanie konsumpcji w cyklu życia za nadrzędne cele funkcjonowania zabezpieczenia emerytalnego ${ }^{11}$. Za cele drugoplanowe przyjmuje zaś: minimalizowanie zakłóceń na rynku pracy, sprzyjanie mobilizacji oszczędności oraz przyczynianie się do rozwoju rynku finansowego.

Jednak zestaw celów w kontekście oceny systemu i jego reform jest w podejściu Banku Światowego bardziej rozbudowany. Zakres oceny systemów powinien obejmować: adekwatność świadczeń (ang. adequacy), możliwość utrzymania w sensie finansowym (ang. affordability), stabilność finansową systemu (ang. sustainability), równość, tzn. takie samo świadczenie za takie same składki (ang. equity), odporność na niekorzystne zdarzenia (ang. robustness) oraz przewidywalność (ang. predictibility), którą rozumie się jako brak dyskrecjonalnych zmian wysokości świadczeń, ochronę przed inflacją czy zmianą wysokości wynagrodzeń bądź kapitału emerytalnego w okresie bezpośrednio poprzedzającym przejście na emeryturę ${ }^{12}$.

Porównanie obszarów oceny systemów zabezpieczenia emerytalnego w propozycjach obu instytucji zaprezentowano w tabeli 1 .

9. M. Żukowski, Otwarta koordynacja zabezpieczenia emerytalnego w Unii Europejskiej - nowy etap europejskiej polityki społecznej?, „Polityka społeczna” 2002, nr 11-12.

10. European Commission, The 2018 Ageing Report: Economic and budgetary projections for the $28 \mathrm{EU}$ Member States (2016-2070), Institutional Paper 079. Brussels, 2018, doi:10.2765/615631 (online); European Commission, Pension adequacy report 2018 - Current and future income adequacy in old age in the EU, Brussels 2018; European Commission, Fiscal Sustainability Report 2018, Institutional Paper 094. Brussels, 2019, doi:10.2765/435292 (online).

11. R. Holzmann, R. Hinz, Old Age Income Support in the 21st Century. An International Perspective on Pension Systems and Reform, Washington, The World Bank, 2005, s. 6.

12. T. Bednarczyk, K. Bielawska, B. Jackowska et al., Ekonomiczne i demograficzne uwarunkowania funkcjonowania i rozwoju ubezpieczeń, Gdańsk, Wydawnictwo Uniwersytetu Gdańskiego, 2019, s. 68-69, na podstawie: R. Holzmann, R. Hinz, M. Dorfman, Pension Systems and Reform Conceptual Framework, SP Discussion Paper 2008, nr 0824, Waszyngton D.C. 
Tabela 1. Obszary oceny i cele reformowania systemów zabezpieczenia emerytalnego w dokumentach Komisji Europejskiej i Banku Światowego

\begin{tabular}{|c|c|c|c|}
\hline \multirow{2}{*}{$\begin{array}{l}\text { Instytucja i źródło } \\
\text { informacji }\end{array}$} & \multicolumn{3}{|l|}{ Obszary oceny systemów } \\
\hline & $\begin{array}{l}\text { adekwatność } \\
\text { (adequacy) }\end{array}$ & $\begin{array}{l}\text { stabilność finansowa } \\
\text { (sustainability) }\end{array}$ & $\begin{array}{l}\text { modernizacja } \\
\text { (modernisation) }\end{array}$ \\
\hline $\begin{array}{l}\text { Komisja Europejska } \\
\text { Adequate and } \\
\text { Sustainable Pensions. } \\
\text { Joint Report } \\
\text { by Commission and the } \\
\text { Council (2003) }\end{array}$ & $\begin{array}{l}\text { - Ochrona przed } \\
\text { ubóstwem } \\
\text { i zapewnienie } \\
\text { godnego poziomu } \\
\text { życia } \\
\text { - Powszechny dostęp } \\
\text { do zabezpieczenia } \\
\text { emerytalnego, aby } \\
\text { osiągnąć odpowiedni } \\
\text { standard życia } \\
\text { na emeryturze (plany } \\
\text { publiczne i prywatne) } \\
\text { - Solidarność wewnątrz- } \\
\text { i międzypokoleniowa }\end{array}$ & $\begin{array}{l}\text { - Działania na rzecz wysokiego } \\
\text { zatrudnienia } \\
\text { - Dbałość o taką organizację } \\
\text { zabezpieczenia emerytalnego, } \\
\text { aby motywowała do pracy } \\
\text { - Reformowanie systemów } \\
\text { z uwzględnieniem trwałości } \\
\text { finansowania } \\
\text { - Równomierne rozkładanie } \\
\text { kosztów reform na poszczególne } \\
\text { pokolenia } \\
\text { - Odpowiednie zasady } \\
\text { funkcjonowania planów } \\
\text { publicznych i prywatnych } \\
\text { (dostępność, efektywność, } \\
\text { bezpieczeństwo } \\
\text { i transferowalność uprawnień/ } \\
\text { kapitału) }\end{array}$ & $\begin{array}{l}\text { - Adaptacja systemu } \\
\text { do zmiany } \\
\text { wzorców } \\
\text { zatrudnienia } \\
\text { i karier } \\
\text { zawodowych } \\
\text { - Zapewnienie } \\
\text { równego } \\
\text { traktowania kobiet } \\
\text { i mężczyzn } \\
\text { - Przejrzystość } \\
\text { i wiarygodność } \\
\text { informacji } \\
\text { o systemie i jego } \\
\text { perspektywach }\end{array}$ \\
\hline $\begin{array}{l}\text { Bank Światowy } \\
\text { Old Age Income Support } \\
\text { in the 21st Century. An } \\
\text { International Perspective } \\
\text { on Pension Systems } \\
\text { and Reform (2005) oraz } \\
\text { R. Holzmann, R. Hinz, } \\
\text { M. Dorfman, Pension } \\
\text { Systemsand Reform }\end{array}$ & $\begin{array}{l}\text { - Ochrona przed } \\
\text { ubóstwem osób } \\
\text { starszych w całej } \\
\text { populacji na poziomie } \\
\text { bezwzględnym } \\
\text { właściwym dla danego } \\
\text { kraju (adequacy) } \\
\text { - Zapewnienie dostępu } \\
\text { do instrumentów }\end{array}$ & $\begin{array}{l}\text { - Możliwość utrzymania w sensie } \\
\text { finansowym, tj. branie pod } \\
\text { uwagę możliwości finansowania } \\
\text { świadczeń przez jednostki } \\
\text { i społeczeństwo bez zagrożenia } \\
\text { realizacji innych ważnych celów } \\
\text { społecznych oraz niemożliwych } \\
\text { do utrzymania konsekwencji } \\
\text { fiskalnych (affordability) }\end{array}$ & $\begin{array}{l}\text { - Odporność } \\
\text { na niekorzystne } \\
\text { zdarzenia, w tym } \\
\text { wynikające } \\
\text { z niestabilności } \\
\text { gospodarczej, } \\
\text { demograficznej } \\
\text { i politycznej } \\
\text { (robustness) }\end{array}$ \\
\hline $\begin{array}{l}\text { Conceptual Framework, } \\
\text { SP Discussion Paper } \\
\text { 2008, nr 0824, } \\
\text { Waszyngton D.C } \\
\text { (rozszerzenie o równość }^{\text {i przewidywalność)* }}\end{array}$ & $\begin{array}{l}\text { wygładzenia } \\
\text { konsumpcji przez całe } \\
\text { życie dla znaczącej } \\
\text { większości populacji } \\
\text { (adequacy) }\end{array}$ & $\begin{array}{l}\text { - Trwałość systemu, czyli } \\
\text { dbanie o dobrą kondycję } \\
\text { finansową, która pozwala } \\
\text { na jego niezakłócone działanie } \\
\text { w przewidywalnej perspektywie } \\
\text { czasowej przy szerokim } \\
\text { zestawie rozsądnych założeń } \\
\text { (sustainability) }\end{array}$ & $\begin{array}{l}\text { - Równość } \\
\text { świadczeń w relacji } \\
\text { do wkładu } \\
\text { (equity) } \\
\text { - Przewidywalność } \\
\text { świadczeń } \\
\text { (predictibility) }\end{array}$ \\
\hline
\end{tabular}

* W oryginalnym dokumencie Banku Światowego każdy z wymienionych w tabeli obszarów jest traktowany odrębnie; przyporządkowanie do obszarów oceny według propozycji autorki.

Źródło: Opracowanie własne na podstawie: European Commission, Adequate and Sustainable Pensions. Joint Report by Commission and the Council, Luxembourg Publication Office, 2003 oraz R. Holzmann, R. Hinz, Old Age Income Support in the 21st Century. An International Perspective on Pension Systems and Reform, Washington, The World Bank, 2005.

Jak wynika z tabeli 1, w podejściu Komisji Europejskiej i Banku Światowego w obszarach oceny i monitorowania funkcjonowania systemów zabezpieczenia emerytalnego jest wiele wspólnych pól. Wiele z tych obszarów można zoperacjonalizować 
poprzez stosowanie odpowiednich miar z uwzględnieniem odniesień do ubezpieczeń społecznych.

\section{Przegląd wskaźników stosowanych w poszczególnych obszarach oceny systemów ubezpieczeń społecznych}

Wydaje się, że w ocenie systemów ubezpieczeń społecznych (podobnie jak w systemach emerytalnych) najczęściej i najdłużej eksplorowany jest obszar adekwatności świadczeń. Biorąc po uwagę, że adekwatność świadczeń ma zarówno wymiar indywidualny, jak i zbiorowy (ochrona przed ubóstwem danej grupy społecznej czy ubezpieczonych), należałoby ją rozważać w szerokim ujęciu. To znaczy, nie tylko przez pryzmat wysokości świadczeń, lecz także ich dostępności. W literaturze przedmiotu takie ujęcie nazywane jest również oceną skuteczności ubezpieczeń społecznych ${ }^{13}$. Zakres podmiotowy ubezpieczeń społecznych powinien być możliwie szeroki, tj. obejmować wszystkich utrzymujących się z pracy zależnej i pracy na własny rachunek (samozatrudnieni). Problematyczne jest obejmowanie ubezpieczeniami społecznymi osób biernych zawodowo, np. utrzymujących się z transferów społecznych. Zwykle, jeśli takie osoby podlegają ubezpieczeniom, to składki finansowane są ze środków publicznych ( $z$ budżetu państwa czy funduszy celowych). Argumentem za obejmowaniem biernych zawodowo przynajmniej niektórymi rodzajami ubezpieczeń społecznych (emerytalnymi czy rentowymi) jest umożliwienie spełnienia w przyszłości warunku otrzymania świadczenia długookresowego (np. posiadanie odpowiednio długiego stażu ubezpieczenia wymaganego do otrzymania emerytury czy renty z tytułu niezdolności do pracy). Ponadto w wielu rozwiniętych państwach na świecie, jeśli nawet ubezpieczenia społeczne są główną techniką realizacji zabezpieczenia społecznego, istnieją odrębne systemy zabezpieczenia wybranych grup zawodowych czy społecznych (służby mundurowe, rolnicy, górnicy itp.). Utrudnia to ocenę zakresu podmiotowego systemu w sposób porównywalny, gdyż w analizach najczęściej brany jest pod uwagę system, który obejmuje największą część populacji. Podstawową miarą dostępności świadczeń w ubezpieczeniach społecznych jest odsetek osób aktywnych ekonomicznie objętych danym rodzajem ubezpieczenia społecznego.

Przechodząc do miar adekwatności w wymiarze pieniężnym, z indywidualnego punktu widzenia najczęściej stosowana jest stopa zastąpienia, która stanowi relację świadczenia (emerytury, renty, zasiłku) do uzyskiwanych wcześniej dochodów

13. M. Kawiński, Ubezpieczenia publiczne i prywatne w polityce społecznej. Skuteczność i efektywność, Warszawa, C.H. Beck, 2011, s. 204. 
wyrażoną procentowo. Odzwierciedla ona podejście dochodowe do oceny adekwatności świadczeń (adekwatność dochodowa). Indywidualna stopa zastąpienia może być podawana w wartościach brutto lub netto (po opodatkowaniu), w odniesieniu do przeciętnego lub ostatniego wynagrodzenia ubezpieczonego. Może również dotyczyć oczekiwanej wartości świadczenia w relacji do wynagrodzenia, przy założeniu różnych scenariuszy kształtowania się kariery zawodowej. Wówczas mówimy o teoretycznej stopie zastąpienia (ang. theoretical replacement rate - TRR).

Wreszcie stopa zastąpienia może być obliczana dla poszczególnych części systemu ubezpieczeń społecznych (świadczenia chorobowe, renty z tytułu niezdolności do pracy, emerytury) na podstawie przeciętnej wysokości świadczenia do przeciętnego wynagrodzenia w gospodarce narodowej ${ }^{14}$, co służy ocenie adekwatności świadczeń $\mathrm{w}$ wymiarze zbiorowym (systemowa stopa zastąpienia). Z perspektywy państwa jako prowadzącego ubezpieczenia społeczne ważna jest też ocena, na ile system chroni przed ubóstwem. Często wykorzystuje się w tym celu absolutne lub relatywne miary ubóstwa, stopę zagrożenia ubóstwem w różnych typach gospodarstw domowych czy wskaźnik pogłębionej deprywacji materialnej w poszczególnych grupach (np. emerytów, rencistów).

Dyskusyjne jest, czy ocena adekwatności świadczeń powinna mieć aspekt dochodowy (zastępowalność uprzednich dochodów), czy raczej wydatkowy (odnoszący się do możliwości pokrycia wydatków na towary i usługi konsumpcyjne stosownie do potrzeb). Jak już zaznaczono we wcześniejszych opracowaniach ${ }^{15}$, na ten drugi aspekt zaczyna się zwracać uwagę w literaturze coraz częściej ${ }^{16}$. Ponadto proponuje się również stosowanie wieloskładnikowych miar oceny adekwatności emerytur. Zaliczyć do nich można miary skuteczności systemu emerytalnego zaproponowane m.in. przez Chybalskiego, które łączą w sobie ocenę ubóstwa wśród emerytów, poziom dochodów oraz zróżnicowanie według płci ubóstwa i dochodów wśród emerytów ${ }^{17}$.

Ocena stabilności finansowej pojawiła się wśród mierników oceny funkcjonowania systemów ubezpieczeń społecznych relatywnie niedawno, jako wyraz wzrostu zainteresowania ekonomicznymi uwarunkowaniami działania systemów, na które coraz większy wpływ ma demografia. Stabilność finansowa jest gwarantem realizacji obiecanych

14. K. Bielawska, Adekwatność emerytur w świetle zmian polskiego systemu emerytalnego, „Zarządzanie i Finanse" 2016, nr 4(14).

15. Ibidem, s. 32.

16. C.R Cole, A.P. Liebenberg, An Examination of Retirement Income Adequacy Measures and factors affecting retirement preparedness, https://ssrn.com/abstract=1272067, dostęp; F. Chybalski, E. Marcinkiewicz, The Replacement Rate: An Imperfect Indicator of Pension Adequacy in Cross-Country Analysis, „Social Indicators Research” 2015, nr 1.

17. F. Chybalski, Skuteczność i efektywność systemu emerytalnego. Koncepcja analizy i próba pomiaru, Łódź, Wydawnictwo Politechniki Łódzkiej, 2012; F. Chybalski, Adekwatność dochodowa [w:] Adekwatność dochodowa, efektywność i redystrybucja w systemach emerytalnych. Ujęcie teoretyczne, metodyczne i empiryczne, red. F. Chybalski, Warszawa, Wydawnictwo C.H. Beck, 2016, s. 22. 
świadczeń, do których ubezpieczeni nabywają prawo, wnosząc wkład do systemu. Pewność i terminowość otrzymania świadczenia jest ważnym narzędziem budowania zaufania do systemu ubezpieczeń i do państwa. Stąd też monitorowanie kondycji finansowej systemu ubezpieczeń społecznych jest jednym z priorytetowych zadań. W odniesieniu do świadczeń krótkoterminowych (np. zasiłki) podstawowym działaniem powinna być ocena samofinansowania świadczeń (ocena równowagi finansowej), czyli pokrycia wydatków wpływami ze składek. Teoretycznie w świadczeniach krótkoterminowych łatwiej jest wprowadzać zmiany determinujące sytuację finansową (stopa składki, zakres podmiotowy, warunki dostępu do świadczeń). Nie zawsze jednak zmiany, które zmierzałyby do zapewnienia równowagi finansowej w obszarze świadczeń krótkoterminowych, są rzeczywiście wdrażane ${ }^{18}$. Analizę wydatków czy salda w funduszach ubezpieczeń społecznych można przeprowadzać zarówno w wartościach bezwzględnych, jak i w relacji do $\mathrm{PKB}$, co ułatwia porównanie z systemami w innych państwach. Ta miara relatywna ma jeszcze tę zaletę, że w sytuacji deficytu można ocenić jego wielkość na tle limitów deficytu całego sektora finansów publicznych, które obowiązują kraje członkowskie $\mathrm{UE}^{19}$ i często są dodatkowo określane w formie reguł fiskalnych (numerycznych ograniczeń agregatów fiskalnych, m.in. salda czy długu sektora finansów publicznych) w ustawodawstwach krajowych. W przypadku świadczeń emerytalnych i rentowych kluczowe jest kontrolowanie zobowiązań i możliwości ich pokrycia w długim okresie (50, 75 lat). Dlatego też stosuje się takie miary jak zobowiązania emerytalno-rentowe brutto i netto ${ }^{20}$ lub bardziej rozbudowane miary prezentowane w Fiscal Sustainability Report w UE, takie jak wskaźniki S1, S2²1. Wpływ na sytuację finansową ubezpieczeń społecznych mają m.in. czynniki demograficzne i ekonomiczne. Dlatego warto monitorować wskaźniki odzwierciedlające relację między osobami w wieku nieprodukcyjnym i produkcyjnym, osobami nieaktywnymi i aktywnymi

18. Przykładem utrwalania deficytu w świadczeniach w razie choroby i macierzyństwa może być sytuacja subfunduszu chorobowego w Funduszu Ubezpieczeń Społecznych. Składka na to ubezpieczenie jest niezmienna (2,45\% podstawy wymiaru) od 1999 roku. Natomiast w wyniku wielu zmian zwiększających dostęp do świadczeń i okres ich pobierania, od 2010 roku występuje w tym subfunduszu deficyt w wysokości 50\% wydatków, co należy ocenić zdecydowanie negatywnie. Por. K. Bielawska, A. Rejmer, Zakres wykorzystania bazy ekonomicznej ubezpieczenia społecznego określany przez przepływy środków pieniężnych [w:] Baza ekonomiczna ubezpieczenia społecznego, red. R. Pacud, Warszawa, Difin, 2019.

19. Sektor ubezpieczeń społecznych jest częścią sektora instytucji rządowych i samorządowych (General Government Sector), a więc jego wpływy, wydatki i zobowiązania netto mają wpływ na wynik i zadłużenie całego sektora. W prawie polskim używa się określenia „sektor finansów publicznych”, które różni się od definicji sektora instytucji rządowych i samorządowych w UE, lecz ZUS i zarządzane przez niego fundusze wchodzą w skład sektora finansów publicznych.

20. Publikacja zobowiązań emerytalnych i rentowych jest obowiązkowa dla krajów członkowskich UE co trzy lata począwszy od 2015 roku. Wycena zobowiązań następuje według jednolitych zasad, co zapewnia porównywalność informacji.

21. European Commission, Fiscal Sustainability Report 2018, Institutional Paper 094, Brussels, 2019, doi:10.2765/435292 (online). 
ekonomicznie czy pobierającymi świadczenia i opłacającymi składki do systemu ubezpieczeń społecznych (odpowiednio wskaźnik obciążenia demograficznego, wskaźnik obciążenia ekonomicznego, wskaźnik obciążenia systemowego). Ocena stabilności finansowej wymaga monitorowania nie tylko zmian demograficznych (w tym migracji), lecz także sytuacji na rynku pracy (wzrost wskaźników zatrudnienia, zwłaszcza wśród osób w wieku 50+ czy wydłużanie okresów zatrudnienia, aby lepiej równoważyć okresy zatrudnienia i pobierania świadczeń emerytalnych). Te ostatnie elementy włączane są do obszaru modernizacji w ujęciu Komisji Europejskiej, jednak niewątpliwie wiążą się ze stabilnością finansową ubezpieczeń społecznych (głównie ubezpieczeń emerytalnych). Omawiane wskaźniki zaprezentowano w tabeli 2.

Tabela 2. Operacjonalizacja obszarów oceny systemów ubezpieczeń społecznych przez stosowanie wskaźników

\begin{tabular}{|c|c|c|}
\hline \multicolumn{3}{|c|}{ Obszary oceny i przyporządkowane im wskaźniki } \\
\hline Adekwatność & Stabilność finansowa & Modernizacja \\
\hline $\begin{array}{l}\text { Adekwatność podmiotowa: } \\
\text { 1) Odsetek osób ekonomicznie aktywnych } \\
\text { (wykonujących pracę zależną oraz } \\
\text { na własny rachunek) objętych } \\
\text { ubezpieczeniami społecznymi }\end{array}$ & $\begin{array}{l}\text { Krótkookresowa: } \\
\text { 1) Saldo systemu w wartościach } \\
\text { absolutnych lub relatywnych } \\
\text { (np. w relacji do PKB w \%) } \\
\text { 2) Wskaźnik pokrycia wydatków } \\
\text { wpływami ze składek (w \%) }\end{array}$ & $\begin{array}{l}\text { 1) Średni czas aktywności } \\
\text { zawodowej (zmiana } \\
\text { W czasie) } \\
\text { 2) W ubezpieczeniu } \\
\text { emerytalnym: rozpiętość } \\
\text { między wiekiem }\end{array}$ \\
\hline $\begin{array}{l}\text { Adekwatność świadczeniowa w wymiarze } \\
\text { indywidualnym: } \\
\text { 1) Indywidualna stopa zastąpienia } \\
\text { (brutto, netto; względem ostatniego } \\
\text { wynagrodzenia, względem przeciętnego } \\
\text { wynagrodzenia z kariery zawodowej) } \\
\text { 2) Teoretyczne stopy zastąpienia dla różnych } \\
\text { karier zawodowych (brutto, netto) }\end{array}$ & $\begin{array}{l}\text { Długookresowa - } \\
\text { uwarunkowania: } \\
\text { 1) Wskaźnik obciążenia } \\
\text { demograficznego } \\
\text { 2) Wskaźnik obciążenia } \\
\text { ekonomicznego } \\
\text { 3) Wskaźnik obciazżenia } \\
\text { systemowego }\end{array}$ & $\begin{array}{l}\text { emerytalnym a czasem } \\
\text { trwania życia w dobrym } \\
\text { zdrowiu (zmiana w czasie) } \\
\text { 3) W ubezpieczeniu } \\
\text { emerytalnym: rozpiętość } \\
\text { między wiekiem } \\
\text { emerytalnym a średnim } \\
\text { dalszym czasem trwania } \\
\text { życia w wieku emerytalnym }\end{array}$ \\
\hline $\begin{array}{l}\text { Adekwatność świadczeniowa w wymiarze } \\
\text { zbiorowym: } \\
\text { 1) Systemowa stopa zastąpienia } \\
\text { (brutto, netto) } \\
\text { 2) Odsetek osób otrzymujących świadczenia } \\
\text { minimalne lub poniżej przyjętej wartości } \\
\text { (zmiana w czasie) } \\
\text { 3) Absolutne i relatywne miary ubóstwa } \\
\text { w różnych typach gospodarstw domowych } \\
\text { 4) Stopa zagrożenia ubóstwem w różnych } \\
\text { typach gospodarstw domowych } \\
\text { 5) Wskaźnik pogłębionej deprywacji } \\
\text { materialnej w różnych typach gospodarstw } \\
\text { domowych }\end{array}$ & $\begin{array}{l}\text { Długookresowa - sfera } \\
\text { finansowa: } \\
\text { 1) Saldo długoterminowe } \\
\text { w relacji do PKB lub } \\
\text { podstawy wymiaru składek } \\
\text { (w \%) - luka składkowa } \\
\text { 2) Zobowiązania z tytułu } \\
\text { świadczeń emerytalnych } \\
\text { i rentowych (brutto i netto) } \\
\text { w relacji do PKB w \% } \\
\text { 3) Wskaźniki S1 i S2* }\end{array}$ & $\begin{array}{l}\text { 4) W ubezpieczeniu } \\
\text { emerytalnym: okres } \\
\text { pobierania emerytury } \\
\text { ( z uwzględnieniem płci) } \\
\text { 5) Analiza wrażliwości } \\
\text { np. salda funduszy } \\
\text { ubezpieczeń społecznych } \\
\text { wyrażonego w relacji } \\
\text { do PKB (czy w liczbach } \\
\text { bezwzględnych) } \\
\text { na zmiany poszczególnych } \\
\text { parametrów } \\
\text { demograficznych } \\
\text { i ekonomicznych }\end{array}$ \\
\hline
\end{tabular}

*Wskaźniki stosowane przez Komisję Europejską w Fiscal Sustainability Reports.

Źródto: Opracowanie własne. 
Kolejny obszar oceny związany jest z postulatami takiego reformowania zwłaszcza świadczeń długoterminowych, które zwiększy zdolności absorpcji szoków o charakterze demograficznym (wzrost udziału w populacji osób w wieku poprodukcyjnym w stosunku do osób w wieku produkcyjnym), ekonomicznym (kryzys ekonomiczny, finansowy, fiskalny) oraz czynników o charakterze politycznym. W wymiarze ilościowym monitorowanie tej odporności realizowane jest przez analizę wrażliwości, np. salda funduszy ubezpieczeń społecznych wyrażonego w relacji do PKB (czy w liczbach bezwzględnych) na zmiany poszczególnych parametrów demograficznych i ekonomicznych, zgodnie z zakładanymi scenariuszami. Zmiana każdego parametru o jeden punkt procentowy pokazuje siłę jego oddziaływania na saldo i możliwość absorpcji negatywnych zmian w otoczeniu systemu. W wymiarze jakościowym warto podkreślić np. stosowanie przez wiele państw tzw. automatycznych mechanizmów bilansujących w ubezpieczeniach społecznych (zwłaszcza w części emerytalnej i rentowej). Są to mechanizmy, które umocowane $\mathrm{w}$ ramach prawnych działają automatycznie, poprawiając sytuację finansową i wypłacalność systemu i nie wymagają podejmowania decyzji politycznych ${ }^{22}$. W odniesieniu do emerytur kluczowe z punktu widzenia zarówno stabilności finansowej, jak i adekwatności świadczeń jest lepsze zbilansowanie okresów aktywności zawodowej i czasu na emeryturze. Dlatego też jednym z narzędzi zwiększania odporności na zmianę demograficzną jest automatyczne podwyższanie wieku emerytalnego, stosownie do zmian w czasie trwania życia.

Równość w odniesieniu do wysokości świadczeń jest relatywnie nowym obszarem oceny i niejednoznacznym, zwłaszcza na poziomie operacjonalizacji. Wyczerpujące studium zagadnienia równości przedstawiła J. Ratajczak, analizując tę kwestię na przykładzie polskiego systemu emerytalnego ${ }^{23}$. Ekonomiści, pisząc o równości w kontekście świadczeń, mają na myśli takie samo świadczenie w zamian za tę samą wysokość składek. Tymczasem jest to tylko jeden z obszarów równości, który może stać w sprzeczności z równością w innych obszarach (równość potrzeb, równość sytuacji, równość szans) $)^{24}$.

22. C. Vidal-Meliá, M. Boado-Penas, O. Settergren, Automatic Balance Mechanisms in Pay-As-YouGo Pension Systems, „Geneva Papers on Risk and Insurance” 2009, Vol. 34, s. 287-317. https://doi. org/10.1057/gpp.2009.2, dostęp; T. Jedynak, Automatic Balance Mechanisms as instruments of maintaining pension scheme financial sustainability, „Rozprawy Ubezpieczeniowe. Konsument na rynku usług finansowych" 2018, nr 29, s. 66-85.

23. J. Ratajczak, Równość w systemie emerytalnym. Emerytury kobiet i mężczyzn w Polsce, Poznań, Wydawnictwo Uniwersytetu Ekonomicznego w Poznaniu, 2019.

24. Ibidem. 


\section{Obszary oceny wymagające wzmocnienia w kontekście starzenia się populacji}

Z perspektywy poglądów autorki konieczne jest podjęcie działań, które urealnią prowadzenie oceny systemu ubezpieczeń społecznych w zakresie możliwości utrzymania w sensie finansowym przez kolejne pokolenia (ang. affordability), akceptowalności skali redystrybucji (ang. redistribution) oraz przejrzystości (ang. transparency). Potrzeba taka występuje zwłaszcza w odniesieniu do systemu ubezpieczeń społecznych w Polsce.

Ocena możliwości utrzymania systemu ubezpieczeń społecznych powinna być rozpatrywana zarówno z punktu widzenia kosztów pracy (stopa składek), jak i pogodzenia utrzymania systemu bez kolizji z innymi ważnymi celami społecznymi. W obszarze polityk publicznych niemal wszystko jest sprawą wyboru i nadawania priorytetów. W sytuacji dynamicznego starzenia się ludności konieczne jest uwzględnianie interesów wszystkich pokoleń w równym stopniu. Tymczasem wiele zmian systemu ubezpieczeń społecznych lub innych programów społecznych (finansowanych ze środków publicznych) jest wprowadzanych bez analizy długookresowych skutków i rozkładu ich kosztów na kolejne pokolenia. To samo można powiedzieć o świadomości skali redystrybucji w systemie ubezpieczeń społecznych. Redystrybucja w systemach ubezpieczeń społecznych występuje zawsze (w wymiarze indywidualnym wewnątrz- i międzypokoleniowym), natomiast jej nasilenie zależy od wielu czynników. Nie jest też łatwo zoperacjonalizować i zmierzyć efekty redystrybucyjne. Obszerne studium w zakresie redystrybucji w polskim systemie emerytalnym przedstawiła J. Rutecka ${ }^{25}$. Redystrybucja wewnątrzpokoleniowa zachodzi pomiędzy osobami urodzonymi w podobnym okresie, np. redystrybucja od mężczyzn do kobiet ze względu na stosowanie uniwersalnych tablic trwania życia, dopłaty do emerytur minimalnych, natomiast redystrybucja międzypokoleniowa występuje, gdy skapitalizowana wartość opłaconych składek nie będzie korespondowała $\mathrm{z}$ wartością świadczeń emerytalnych ${ }^{26}$. Skala redystrybucji, zwłaszcza w ubezpieczeniu emerytalnym, powinna być komunikowana opinii publicznej. Nie jest łatwo zmierzyć skalę redystrybucji, zwłaszcza w sposób, który byłby zrozumiały dla społeczeństwa. Niemniej, w literaturze przedmiotu można znaleźć propozycje

25. J. Rutecka, Zakres redystrybucji dochodowej w ubezpieczeniowym systemie emerytalnym, Warszawa, Oficyna Wydawnicza SGH, 2012.

26. F. Chybalski, Pomiar redystrybucji w międzynarodowych analizach systemów emerytalnych [w:] Wspótczesne problemy systemów emerytalnych. Wybrane zagadnienia, red. F. Chybalski i E. Marcinkiewicz, Monografie Politechniki Łódzkiej, Łódź 2015, s. 20. 
interesujące również w wymiarze przekazu. Chybalski proponuje wskaźnik symptomów redystrybucji bazujący na wskaźniku nierównomierności dochodów. Jeśli relacja miernika S80/S20 w populacji 65- do miernika S80/S20 w populacji $65+$ jest większa niż 1, oznacza to występowanie redystrybucji w systemie emerytalnym, albowiem w populacji emerytów zróżnicowanie dochodów jest mniejsze niż w populacji aktywnych zawodowo ${ }^{27}$. Pomimo ograniczeń, o których wspomina autor wskaźnika symptomów redystrybucji, wydaje się on interesującym przykładem pomiaru do rozważenia.

Transparentność $\mathrm{w}$ zakresie ubezpieczeń społecznych powinna być elementem oceny w ramach transparentności fiskalnej. Kwestie te od lat podnoszone są w literaturze przedmiotu, a praktycznego znaczenia nabrały z początkiem XXI wieku. Propozycje różnych miar oceny transparentności proponowane są np. przez organizacje międzynarodowe takie jak Międzynarodowy Fundusz Walutowy. „Zdaniem Copitsa i Craiga przejrzystość fiskalna wiąże się z łatwym dostępem do wiarygodnej, kompleksowej, terminowej, zrozumiałej, porównywalnej międzynarodowo informacji na temat działań rządu, umożliwiającej elektoratowi i rynkom finansowym dokładną ocenę sytuacji finansowej państwa oraz rzeczywistych korzyści i kosztów działań rządu, w tym ich obecnych oraz przyszłych skutków ekonomicznych i społecznych"28. Rolę taką w odniesieniu do systemu ubezpieczeń społecznych mogłaby odegrać niezależna rada fiskalna albo aktuariusz krajowy, który notabene miał być powołany po wprowadzeniu reformy emerytalnej w 1999 roku. Jednak żadnego z tych organów w Polsce nie ma, a zakres i sposób przekazywania informacji, zwłaszcza o przyszłej sytuacji ubezpieczeń społecznych oraz ocenie skutków społecznych i ekonomicznych wprowadzanych zmian, pozostawia wiele do życzenia.

\section{Podsumowanie}

W artykule przeprowadzono analizę celów i obszarów oceny systemów ubezpieczeń społecznych przy zastosowaniu odniesień do rekomendacji Komisji Europejskiej i Banku Światowego dla systemów zabezpieczenia emerytalnego. O ile ocena adekwatności i stabilności systemu ubezpieczeń społecznych jest dobrze rozpoznana, o tyle kwestie związane z równością, akceptowaną skalą redystrybucji dochodów (wykraczającą poza czynnik losowy) oraz przejrzystością i wiarygodnością

27. Ibidem, s. 23.

28. Cytat za: E. Malinowska-Misiąg, Wprowadzenie do problematyki jawności i przejrzystości finansów publicznych [w:] Jawność i przejrzystość finansów publicznych, red. E. Malinowska-Misiąg, Warszawa, Oficyna Wydawnicza SGH, 2017, s. 11. 
informacji o systemie ubezpieczeń społecznych są relatywnie słabiej rozpoznane. W czasach dynamicznego starzenia się populacji autorka za konieczne uznaje zwiększenie transparentności, zrozumiałości i przejrzystości informacji o stopniu realizacji celów, ich ewentualnych modyfikacjach i skutkach dla funkcjonowania systemów ubezpieczeń społecznych, a także skutkach społecznych i ekonomicznych w długim okresie. Ze względu na trwałe zmiany demograficzne pokolenia pracujących (objętych ubezpieczeniami społecznymi) powinny być informowane o skali redystrybucji realizowanej przez system ubezpieczeń społecznych, o konsekwencjach finansowych proponowanych czy wprowadzanych zmian w systemach ubezpieczeń społecznych z uwzględnieniem odpowiedniego horyzontu czasowego. Wydaje się, że skuteczny i wiarygodny przekaz w zakresie sytuacji ubezpieczeń społecznych powinien być realizowany przez niezależną instytucję. Wraz z wprowadzeniem reformy ubezpieczeń społecznych w Polsce w 1999 roku proponowano utworzenie urzędu Aktuariusza Krajowego, jednak urząd ten nie powstał. Członkostwo w Unii Europejskiej powinno obligować nas do utworzenia niezależnej rady fiskalnej, jednak organ taki również nie istnieje. Brak niezależnych gremiów utrudnia komunikację i dostęp do rzetelnej informacji o oczekiwanej sytuacji ubezpieczeń społecznych w przyszłości. Wiarygodność informacji pozwala zbudować zaufanie do systemu. Bez zaufania realizacja celów ubezpieczeń społecznych może być zagrożona.

\section{Bibliografia}

Barr N., Diamond P., Economics of pensions, „Oxford Review of Economic Policy” 2006, Vol. 22 (1).

Barr N., Państwo dobrobytu jako skarbonka. Informacja, ryzyko, niepewność a rola państwa, Warszawa, Wydawnictwo Wyższej Szkoły Pedagogicznej TWP w Warszawie, 2010.

Bednarczyk T.H., Bielawska K., Jackowska B. et al., Ekonomiczne i demograficzne uwarunkowania funkcjonowania i rozwoju ubezpieczeń, Gdańsk, Wydawnictwo Uniwersytetu Gdańskiego, 2019.

Bielawska K., Rejmer A., Zakres wykorzystania bazy ekonomicznej ubezpieczenia społecznego określany przez przepływy środków pieniężnych [w:] Baza ekonomiczna ubezpieczenia społecznego, red. R. Pacud, Warszawa, Difin, 2019.

Bielawska K., Adekwatność emerytur w świetle zmian polskiego systemu emerytalnego, „Zarządzanie i Finanse" 2016, nr 4 (14).

Chybalski F., Adekwatność dochodowa [w:] Adekwatność dochodowa, efektywność i redystrybucja w systemach emerytalnych. Ujęcie teoretyczne, metodyczne i empiryczne, red. F. Chybalski, Warszawa, Wydawnictwo C.H. Beck, 2016.

Chybalski F., Marcinkiewicz E., The Replacement Rate: An Imperfect Indicator of Pension Adequacy in Cross-Country Analysis, „Social Indicators Research” 2015, nr 1. 


\section{Monitorowanie i ocena systemów ubezpieczeń społecznych}

Chybalski F., Pomiar redystrybucji w międzynarodowych analizach systemów emerytalnych [w:] Wspótczesne problemy systemów emerytalnych. Wybrane zagadnienia, red. F. Chybalski i E. Marcinkiewicz, Monografie Politechniki Łódzkiej, Łódź 2015.

Chybalski F., Skuteczność i efektywność systemu emerytalnego. Koncepcja analizy i próba pomiaru, Łódź, Wydawnictwo Politechniki Łódzkiej, 2012.

Cole C.R., Liebenberg A.P., An Examination of Retirement Income Adequacy Measures and factors affecting retirement preparedness, https://ssrn.com/abstract=1272067, dostęp

European Commission, The 2018 Ageing Report: Economic and budgetary projections for the 28 EU Member States (2016-2070), Institutional Paper 079, Brussels, 2018, doi:10.2765/615631 (online).

European Commission, Pension Adequacy Report 2018 - Current and future income adequacy in old age in the EU, Brussels 2018.

European Commission, Fiscal Sustainability Report 2018, Institutional Paper 094, Brussels, 2019, doi:10.2765/435292 (online).

European Commission, Adequate and Sustainable Pensions. Joint Report by the Commission and the Council, Luxemburg 2003.

Golinowska S., Polityka społeczna państwa w gospodarce rynkowej. Studium ekonomiczne, Warszawa, Wydawnictwo Naukowe PWN, 1994.

Holzmann R., Hinz R., Dorfman M., Pension Systems and Reform Conceptual Framework, SP Discussion Paper 2008, nr 0824, Waszyngton D.C.

Holzmann R., Hinz R., Old Age Income Support in the 21st Century. An International Perspective on Pension Systems and Reform, Washington, The World Bank, 2005.

Jedynak T., Automatic Balance Mechanisms as instruments of maintaining pension scheme financial sustainability, „Rozprawy Ubezpieczeniowe. Konsument na rynku usług finansowych” 2018, nr 29.

Kawiński M., Ubezpieczenia publiczne i prywatne w polityce społecznej. Skuteczność i efektywność, Warszawa, C.H. Beck, 2011.

Konwencja Nr 102 Międzynarodowej Organizacji Pracy dotycząca minimalnych norm zabezpieczenia społecznego, Dz. U. 2005 nr 93 poz. 775.

Malinowska-Misiąg E., Wprowadzenie do problematyki jawności i przejrzystości finansów publicznych [w:] Jawność i przejrzystość finansów publicznych, red. E. Malinowska-Misiąg, Warszawa, Oficyna Wydawnicza SGH, 2017.

Ratajczak J., Równość w systemie emerytalnym. Emerytury kobiet i mężczyzn w Polsce, Poznań, Wydawnictwo Uniwersytetu Ekonomicznego w Poznaniu, 2019.

Rutecka J., Zakres redystrybucji dochodowej w ubezpieczeniowym systemie emerytalnym, Warszawa, Oficyna Wydawnicza SGH, 2012.

Szumlicz T., Ubezpieczenie. W sprawie zastrzeżenia terminologicznego, „Wiadomości Ubezpieczeniowe” 2009, nr 1 . 


\section{Monitorowanie i ocena systemów ubezpieczeń społecznych}

Vidal-Meliá C., Boado-Penas M., Settergren O., Automatic Balance Mechanisms in Pay-As-You-Go Pension Systems, „Geneva Papers on Risk and Insurance” 2009, nr 34, https://doi.org/10.1057/ gpp.2009.2, dostęp

Żukowski M., Otwarta koordynacja zabezpieczenia emerytalnego w Unii Europejskiej - nowy etap europejskiej polityki społecznej?, „Polityka społeczna” 2002, nr 11-12. 


\title{
Monitoring and assessment of social security systems - review of the criteria proposed by the European Commission and the World Bank and proposals for their extension in the context of an aging population
}

\author{
Kamila Bielawska
}

\begin{abstract}
Social security in many countries is an essential part of the social security system. Due to the specific features of social insurance, inter alia, equivalence and claim ability of benefits or the separate sources of financing, it is necessary to ensure that stakeholders have constant access to reliable information about them, both in terms of the current state and in a sufficiently long time horizon. This should foster confidence in social security.

The aim of the article is to review the areas and criteria used to assess social security systems based on the adaptation of the recommendations of the European Commission and the World Bank with regard to pension systems, and to indicate areas, the assessment of which should become more important in the light of the aging of the population.

As the analysis shows, the assessment of the adequacy and financial stability is developed and constitutes a certain standard. On the other hand, the area related to the modernisation of social insurance, i.e. adapting it to the changing demographic and economic situation, is still a challenge. Too little is assigned to the assessment of gender equality, the scale of redistribution, transparency and credibility of social security information.
\end{abstract}

Keywords: assessment, social security, indicators.

Kamila Bielawska, PhD, assistant professor at the Department of Banking and Finance, Faculty of Management, University of Gdańsk. 


\section{Introduction}

Social security systems in most developed countries are an important source of transfers replacing and/or supplementing the income of the population in the event of the materialisation of social risk. In many of these systems, the method of insurance plays a dominant role, as compared to other techniques of implementing social security, it is distinguished by specific features. According to the views of many authorities in the analysed area, which is shared by the author of this study, the use of the insurance method in social security systems is associated with the need to introduce certain exceptions from the classic features of insurance as a unique method of dealing with risk ${ }^{1}$. The development of social insurance and its obligations towards future generations are becoming an increasing challenge in the context of demographic change and its economic consequences. Also, socio-cultural changes (changing the family pattern, increasing individualism, increasing mobility and forms of earning money, etc.) require greater reflection in social insurance systems.

The aim of the article is to review the areas and indicators used to monitor and assess social security systems on the basis of the recommendations of the European Commission and the World Bank, and to indicate areas whose assessment should be more emphasised in the light of the aging of the population. The article implements the criteria described in the literature on the subject as used for the analysis of pension systems ${ }^{2}$. Many of them may be directly applicable to the assessment of social insurance systems in relation to long-term and short-term benefits, which was illustrated with examples and modification of selected indicators.

1. An overview of the differences in insurance principles with regard to social and private insurance, presented in the Polish literature on the subject, is presented, inter alia, by M. Kawiński [in:] M. Kawiński, Ubezpieczenia publiczne i prywatne w polityce społecznej. Skuteczność i efektywność, Warszawa, Wydawnictwo C.H. Beck, 2011, p. 53 et seq. On the differences in the elements of social insurance in comparison to private insurance also [in:] S. Golinowska, Polityka społeczna państwa w gospodarce rynkowej. Studium ekonomiczne, Warszawa, Wydawnictwo Naukowe PWN, 1994.

2. Cf. T.H. Bednarczyk, K. Bielawska, B. Jackowska et al., Ekonomiczne i demograficzne uwarunkowania funkcjonowania i rozwoju ubezpieczeń, Gdańsk, Wydawnictwo Uniwersytetu Gdańskiego, 2019, p. $68-70$. 


\section{Purposes of functioning and criteria for the assessment of social insurance}

Social insurance is one of the techniques (methods) of dealing with social risk, the materialisation of which causes the loss (total or partial) of earning potential. From the point of view of people who make a living from dependent work, this means the loss or significant reduction of their main source of income. This is a significant problem, especially for those societies that have not yet achieved a satisfactory material status or/and do not use private insurance in this area due to an income barrier, lack of availability of appropriate insurance products or lack of awareness of certain needs (e.g. access to long-term care). Persons exposed to a certain type of social risk (illness, accident at work, loss of a breadwinner, reaching retirement age) form an insurance community by law, pay contributions (contributions may also be financed or co-financed by employers) to the insurance fund, and in the event of risk materialisation and after fulfilling the conditions, they receive the due benefit, which should be related to the contribution to the system ${ }^{3}$.

Due to the mechanism and principles of operation, as well as the social and economic dimension, the social insurance system should be monitored both on an ongoing and long-term basis in terms of achieving the set goals.

The objectives of the functioning of the social insurance system can be considered from the point of view of the individual (participant) and the state as the initiator and operator of social insurance. From the participant's perspective, it is important that the conditions of access to benefits (pensions, disability pensions, sickness benefits) and their amount are accepted by the insured (benefits should adequately replace the temporary or permanent loss of income from work), and that the period of payment of benefits should be adjusted to the effects of the risk (e.g. in retirement insurance, the payment should be life-long; for other benefits, an appropriate balance should be sought, so that too long a period of receiving the benefit does not demotivate people in terms of returning to the labour market, if it is possible). Minimum standards both in terms of the conditions of access to benefits and their relative amount, regardless of the technique of social security implementation,

3. In Polish, the term "insurance premium" is used both in relation to private and social insurance, although these categories are not identical. The premium is the equivalent of insurance cover, while the social security premium is more of a contribution to an insurance fund, the calculation of which does not take into account the risk contributed to the insurance community. This also has consequences for the calculation of benefits. For more on these problems cf. T. Szumlicz, Ubezpieczenie. W sprawie zastrzeżenia terminologicznego, "Wiadomości Ubezpieczeniowe" 2009, nr 1. 
for the so-called average recipient are designated by the Convention No. 102 of the International Labour Organisation, which Poland ratified in $2004^{4}$. By paying the contributions, the participant of the system limits the current consumption in order to be able to consume in the period of materialisation of social risk, which is why in the literature this goal is often referred to as equalising consumption in the life cycle ${ }^{5}$.

The most common goals for the operation of pension systems at the level of the system organiser are protection against poverty and redistribution of income ${ }^{6}$. However, as Chybalski points out ${ }^{7}$, income redistribution is not so much a goal in the pension system as a tool to reduce poverty among retirees. These goals can also be attributed to social insurance, as their structure is usually set so that participants can achieve the appropriate amount of benefits, and they allow for a redistribution of income beyond the random factor. At the same time, it would not be possible to ensure a minimum adequacy of benefits if the social security system was not financially stable in the long term. The reality of insurance protection in any system (public or private) should be ensured by effective financial management as well as the sustainability and sufficiency of financing sources.

Contemporary systems are also faced with goals related to adaptation to changing conditions (demographic, economic, socio-cultural). Such an approach can be found, inter alia, in documents of the European Commission, which in 2003 published a report entitled "Adequate and Sustainable Pensions. Joint Report by the Commission and the Council", in which the open method of coordination (OMC) identifies three areas (goals) of activities of the Member States in the field of pension security: adequacy, financial stability and modernisation. Social policy of the European Union Member States is not subject to harmonisation, but requires coordination due to the similar challenges and the need to exchange information on current and planned reforms ${ }^{9}$. Since then, reports on the impact of the aging population on the budgetary position of EU Member States, reports on pension adequacy

4. Convention No. 102 of the International Labour Organisation on Minimum Standards of Social Security, Journal of Laws 2005 No. 93 pos. 775.

5. N. Barr, P. Diamond, Economic of pensions, “Oxford Review of Economic Policy" 2006, Vol. 22(1); N. Barr, Państwo dobrobytu jako skarbonka. Informacja, ryzyko, niepewność a rola państwa, Warszawa, Wydawnictwo Wyższej Szkoły Pedagogicznej TWP w Warszawie, 2010.

6. Cf. N. Barr, P. Diamond, Economic of pensions, "Oxford Review of Economic Policy" 2006, Vol. 22(1).

7. F. Chybalski, Pomiar redystrybucji w międzynarodowych analizach systemów emerytalnych [in:] Wspótczesne problemy systemów emerytalnych. Wybrane zagadnienia, ed. F. Chybalski i E. Marcinkiewicz, Monografie Politechniki Łódzkiej, Łódź 2015, p. 18.

8. European Commission, Adequate and Sustainable Pensions. Joint Report by the Commission and the Council, Luxemburg 2003.

9. M. Żukowski, Otwarta koordynacja zabezpieczenia emerytalnego w Unii Europejskiej - nowy etap europejskiej polityki społecznej?, "Polityka społeczna” 2002, nr 11-12. 
and fiscal sustainability, taking into account the costs of social programs sensitive to demographic change, have been prepared regularly (every 3 years ${ }^{10}$. It is worth mentioning that due to the frequent interconnection of retirement and disability pensions in social insurance systems, the analyses presented in these reports refer to both types of long-term benefits. On the other hand, from the point of view of short-term benefits, adequacy is important and can be assessed in the same way as for pensions, while financial stability can be monitored on an ongoing basis through the prism of the balance of the fund financing benefits (provided that it is separate from long-term benefits).

Among international organisations, the World Bank also considers protection against poverty and smoothing consumption in the life cycle to be the overarching goals of the functioning of the pension security ${ }^{11}$. The secondary goals are: minimising disruptions in the labour market, promoting the mobilisation of savings and contributing to the development of the financial market.

However, the set of goals in the context of the assessment of the system and its reforms is more extensive in the World Bank's approach. The scope of system assessment should include: adequacy, affordability, system sustainability, equality, i.e. the same benefit for the same premiums (equity), robustness and predictability, which is understood as the lack of discretionary changes in the amount of benefits, protection against inflation or changes in the amount of wages or pension capital in the period immediately preceding retirement ${ }^{12}$.

Table 1 presents a comparison of the areas of assessment of pension security systems in the proposals of both institutions.

10. European Commission, The 2018 Ageing Report: Economic and budgetary projections for the $28 \mathrm{EU}$ Member States (2016-2070), Institutional Paper 079. Brussels, 2018, doi:10.2765/615631 (online); European Commission, Pension adequacy report 2018 - Current and future income adequacy in old age in the EU, Brussels 2018; European Commission, Fiscal Sustainability Report 2018, Institutional Paper 094. Brussels, 2019, doi:10.2765/435292 (online).

11. R. Holzmann, R. Hinz, Old Age Income Support in the 21st Century. An International Perspective on Pension Systems and Reform, Washington, The World Bank, 2005, p. 6.

12. T. Bednarczyk, K. Bielawska, B. Jackowska et al., Ekonomiczne i demograficzne uwarunkowania funkcjonowania i rozwoju ubezpieczeń, Gdańsk, Wydawnictwo Uniwersytetu Gdańskiego, 2019, p. 68-69, based on: R. Holzmann, R. Hinz, M. Dorfman, Pension Systems and Reform Conceptual Framework, SP Discussion Paper 2008, No. 0824, Washington D.C. 
Table 1. Assessment areas and goals of reforming retirement security systems in the documents of the European Commission and the World Bank

\begin{tabular}{|c|c|c|c|}
\hline \multirow{2}{*}{$\begin{array}{l}\text { Institution } \\
\text { and source of } \\
\text { information }\end{array}$} & \multicolumn{3}{|c|}{ Systems assessment areas } \\
\hline & adequacy & sustainability & modernisation \\
\hline $\begin{array}{l}\text { European } \\
\text { Commission } \\
\text { Adequate and } \\
\text { Sustainable Pensions. } \\
\text { Joint Report } \\
\text { by Commission and } \\
\text { the Council (2003) }\end{array}$ & $\begin{array}{l}\text { - Protection against } \\
\text { poverty and } \\
\text { ensuring a decent } \\
\text { standard of living } \\
\text { - Universal access } \\
\text { to pension security } \\
\text { to achieve an } \\
\text { adequate standard } \\
\text { of living in } \\
\text { retirement (public } \\
\text { and private plans) } \\
\text { - Intra- and } \\
\text { intergenerational } \\
\text { solidarity }\end{array}$ & $\begin{array}{l}\text { - Actions for high employment } \\
\text { - Caring for the organisation } \\
\text { of the retirement pension } \\
\text { system in such a way that it } \\
\text { motivates to work } \\
\text { - Reforming the systems } \\
\text { taking into account the } \\
\text { sustainability of financing } \\
\text { - Spreading the cost of reform } \\
\text { evenly across generations } \\
\text { - Appropriate rules for the } \\
\text { functioning of public and } \\
\text { private plans (availability, } \\
\text { efficiency, security and } \\
\text { transferability of allowances/ } \\
\text { capital) }\end{array}$ & $\begin{array}{l}\text { - Adaptation of the } \\
\text { system to changes in } \\
\text { employment patterns } \\
\text { and professional } \\
\text { careers } \\
\text { - Ensuring equal } \\
\text { treatment of women } \\
\text { and men } \\
\text { - Transparency } \\
\text { and credibility of } \\
\text { information about } \\
\text { the system and its } \\
\text { prospects }\end{array}$ \\
\hline $\begin{array}{l}\text { World Bank } \\
\text { Old Age Income } \\
\text { Support in the } \\
\text { 21st Century. An } \\
\text { International } \\
\text { Perspective on } \\
\text { Pension Systems } \\
\text { and Reform (2005) } \\
\text { and R. Holzmann, } \\
\text { R. Hinz, M. Dorfman, } \\
\text { Pension Systems and } \\
\text { Reform Conceptual } \\
\text { Framework, SP } \\
\text { Discussion Paper } \\
\text { 2008, No. 0824, } \\
\text { Washington D.C } \\
\text { (extension to equality } \\
\text { and predictability)* }\end{array}$ & $\begin{array}{l}\text { - Protection against } \\
\text { poverty among } \\
\text { the elderly in the } \\
\text { entire population } \\
\text { at the absolute } \\
\text { level appropriate } \\
\text { for a given country } \\
\text { (a dequacy) } \\
\text { - Providing access } \\
\text { to instruments } \\
\text { for smoothing } \\
\text { consumption } \\
\text { throughout life for } \\
\text { the vast majority } \\
\text { of the population } \\
\text { (a dequacy) }\end{array}$ & $\begin{array}{l}\text { - Maintainability in a financial } \\
\text { sense, i.e. taking into account } \\
\text { the possibility of financing } \\
\text { benefits by individuals } \\
\text { and society without } \\
\text { threatening the achievement } \\
\text { of other important social } \\
\text { goals and unsustainable } \\
\text { fiscal consequences } \\
\text { (affordability) } \\
\text { - System durability, i.e. taking } \\
\text { care of a good financial } \\
\text { condition, which allows for } \\
\text { its uninterrupted operation } \\
\text { in a predictable time } \\
\text { perspective, with a wide set } \\
\text { of reasonable assumptions } \\
\text { (sustainability) }\end{array}$ & $\begin{array}{l}\text { - Resilience to adverse } \\
\text { events, including } \\
\text { those resulting } \\
\text { from economic, } \\
\text { demographic and } \\
\text { political instability } \\
\text { (robustness) } \\
\text { - Equality of } \\
\text { benefits in relation } \\
\text { to contributions } \\
\text { (equity) } \\
\text { - Predictability } \\
\text { of benefits } \\
\text { (predictability) }\end{array}$ \\
\hline
\end{tabular}

* In the original document of the World Bank, each of the areas listed in the table is treated separately; assignment to evaluation areas as proposed by the author.

Source: Own study based on: European Commission, Adequate and Sustainable Pensions. Joint Report by Commission and the Council, Luxembourg Publication Office, 2003 and R. Holzmann, R. Hinz, Old Age Income Support in the 21st Century. An International Perspective on Pension Systems and Reform, Washington, The World Bank, 2005. 
As shown in Table 1, there are many common areas in the approach of the European Commission and the World Bank in the areas of assessment and monitoring of the functioning of pension security systems. Many of these areas can be operationalised by using appropriate measures with reference to social security.

\section{Review of applied indicators in individual areas of assessment of social insurance systems}

It seems that in the assessment of social insurance systems (similarly to pension systems), the area of benefit adequacy is the most frequently and longest explored. Taking into account that the adequacy of benefits has both an individual and a collective dimension (protection against poverty of a given social group or the insured), it should be considered in a broad sense. That is, not only in terms of the amount of benefits, but also their availability. In the literature on the subject, such an approach is also called the assessment of the effectiveness of social insurance ${ }^{13}$. The subjective scope of social insurance should be as wide as possible, i.e. cover all dependent and self-employed workers (the self-employed). It is problematic to cover economically inactive people with social insurance, for example those who make a living from social transfers. Usually, if such persons are subject to insurance, contributions are financed from public funds (from the state budget or earmarked funds). The argument for covering the economically inactive with at least some types of social insurance (retirement or disability pension) is the possibility of meeting the condition of receiving a long-term benefit in the future (e.g. having a sufficiently long period of insurance required to receive a retirement pension or disability pension). Moreover, in many developed countries in the world, even if social insurance is the main technique of implementing social security, there are separate systems of securing certain professional or social groups (uniformed services, farmers, miners, etc.). This makes it difficult to assess the subjective scope of the system in a comparable manner, because the analyses most often take into account the system that covers the largest part of the population. The basic measure of the availability of benefits in social insurance is the percentage of economically active people covered by a given type of social insurance.

Moving on to measures of adequacy in the monetary dimension, from an individual point of view, the replacement rate is the most frequently used, which is the relation of the benefit (retirement pension, disability pension, allowance)

13. M. Kawiński, Ubezpieczenia publiczne i prywatne w polityce społecznej. Skuteczność i efektywność, Warszawa, C.H. Beck, 2011, p. 204. 
to previously obtained income expressed as a percentage. It reflects the income approach to the assessment of the adequacy of benefits (income adequacy). The individual replacement rate may be given in gross or net amounts (after tax), referring to the average or last salary of the insured person. It may also refer to the expected value of the benefit in relation to remuneration, assuming different career development scenarios. Then we are talking about the theoretical replacement rate (TRR).

Finally, the replacement rate can be calculated for individual parts of the social insurance system (sickness benefits, disability pensions, old-age pensions) on the basis of the average benefit amount to the average wage in the national economy ${ }^{14}$, which serves the purpose of assessing the adequacy of benefits in the collective dimension (system replacement rate). From the perspective of the state as a provider of social insurance, it is also important to assess the extent to which the system protects against poverty. For this purpose, absolute or relative poverty measures, the risk of poverty rate in various types of households or the rate of severe material deprivation in particular groups (e.g. retirees, pensioners) are often used.

It is debatable whether the assessment of the adequacy of benefits should have an income aspect (replacement of previous income) or rather an expenditure aspect (relating to the possibility of covering expenditure on consumer goods and services as needed). As already mentioned in previous studies ${ }^{15}$, the latter aspect is becoming increasingly popular in the literature ${ }^{16}$. In addition, it is also proposed to use multicomponent measures to assess the adequacy of pensions. These include measures of the effectiveness of the pension system proposed, inter alia, by Chybalski, which combine the assessment of poverty among retirees, the level of income, and gender differentiation of poverty and income among retirees ${ }^{17}$.

The assessment of financial stability has appeared among the measures for assessing the functioning of social security systems relatively recently, as an expression of an increased interest in the economic conditions of system operation, which is increasingly influenced by demography. Financial stability is a guarantee of the promised benefits to which the insured acquire the right by contributing to the system.

14. K. Bielawska, Adekwatność emerytur w świetle zmian polskiego systemu emerytalnego, "Zarządzanie i Finanse" 2016, nr 4(14).

15. Ibidem, p. 32.

16. C.R Cole, A.P. Liebenberg, An Examination of Retirement Income Adequacy Measures and factors affecting retirement preparedness, https://ssrn.com/abstract=1272067, access; F. Chybalski, E. Marcinkiewicz, The Replacement Rate: An Imperfect Indicator of Pension Adequacy in Cross-Country Analysis, "Social Indicators Research" 2015, nr 1.

17. F. Chybalski, Skuteczność i efektywność systemu emerytalnego. Koncepcja analizy i próba pomiaru, Łódź, Wydawnictwo Politechniki Łódzkiej, 2012; F. Chybalski, Adekwatność dochodowa [in:] Adekwatność dochodowa, efektywność i redystrybucja w systemach emerytalnych. Ujęcie teoretyczne, metodyczne i empiryczne, ed. F. Chybalski, Warszawa, Wydawnictwo C.H. Beck, 2016, p. 22. 
Certainty and timely receipt of benefits is an important tool for building trust in the insurance system and in the state. Hence, monitoring the financial condition of the social security system is one of the priority tasks. With regard to short-term benefits (e.g. benefits), the main activity should be the assessment of self-financing of benefits (assessment of financial balance), i.e. the coverage of expenses with contribution revenues. Theoretically, in the case of short-term benefits, it is easier to introduce changes that determine the financial situation (premium rate, personal scope, conditions of access to benefits). However, not always changes aimed at ensuring financial balance in the area of short-term benefits are actually implement$\mathrm{ed}^{18}$. The analysis of expenditure or balances in social security funds can be carried out both in absolute terms and in relation to GDP, which facilitates comparison with systems in other countries. This relative measure also has the advantage that in the event of a deficit, its size can be assessed against the deficit limits of the entire public finance sector that apply to EU member states ${ }^{19}$ and are often additionally defined in the form of fiscal rules (numerical restrictions on fiscal aggregates, e.g. or debt of the public finance sector) in national legislations. In the case of retirement and disability benefits, the key is to control liabilities and the possibility of covering them in the long term (50, 75 years). Therefore, measures such as gross and net pension liabilities ${ }^{20}$ or more extensive measures presented in the Fiscal Sustainability Report in the UE, such as the S1, S2 indicators ${ }^{21}$, are used. The financial situation of social insurance is influenced, among others, by demographic and economic factors. Therefore, it is worth monitoring indicators reflecting the relationship between people of non-working and working age, inactive and economically active people or people receiving benefits and paying contributions to the social security system (demographic dependency indicator, economic dependency indicator, system

18. An example of consolidating the deficit in sickness and maternity benefits may be the situation of the sickness sub-fund in the Social Insurance Fund (ZUS). The premium for this insurance has not changed (2.45\% of the calculation basis) since 1999 . However, as a result of many changes increasing the access to benefits and the period of receiving them, since 2010 there has been a deficit in this sub-fund in the amount of $50 \%$ of expenditure, which should be assessed strongly negatively. Cf. K. Bielawska, A. Rejmer, Zakres wykorzystania bazy ekonomicznej ubezpieczenia społecznego określany przez przepływy środków pieniężnych [in:] Baza ekonomiczna ubezpieczenia społecznego, ed. R. Pacud, Warszawa, Difin, 2019.

19. The social security sector is part of the General Government Sector, so its net revenues, expenditures and liabilities affect the results and debt of the entire sector. In Polish law, the term "public finance sector" is used, which differs from the definition of the general government sector in the EU, but ZUS and the funds managed by it are part of the public finance sector.

20. Publication of pension liabilities is obligatory for EU member states every three years, starting from 2015. Liabilities are valued according to uniform principles, which ensures the comparability of information.

21. European Commission, Fiscal Sustainability Report 2018, Institutional Paper 094., Brussels, 2019, doi:10.2765/435292 (online). 
burden indicator, respectively). Assessing financial stability requires monitoring not only demographic changes (including migration), but also the situation on the labour market (increasing employment rates, especially among people aged $50+$, or extending employment periods to better balance the periods of employment and retirement benefits). The latter elements are included in the area of modernisation as perceived by the European Commission, but they are undoubtedly related to the financial stability of social insurance (mainly pension insurance). The discussed indicators are presented in Table 2.

Table 2. Operationalisation of the areas of assessment of social insurance systems through the use of indicators

\begin{tabular}{|c|c|c|}
\hline \multicolumn{3}{|c|}{ Assessment areas and associated indicators } \\
\hline adequacy & austainability & modernisation \\
\hline $\begin{array}{l}\text { Subjective adequacy: } \\
\text { 1) Percentage of economically } \\
\text { active people (dependent and } \\
\text { self-employed) covered by social } \\
\text { insurance }\end{array}$ & $\begin{array}{l}\text { Short-term: } \\
\text { 1) Balance of the system in } \\
\text { absolute or relative values } \\
\text { (e.g. in relation to GDP in \%) } \\
\text { 2) The rate of coverage of } \\
\text { expenses with revenues from } \\
\text { contributions (in \%) }\end{array}$ & $\begin{array}{l}\text { 1) Average duration of } \\
\text { economic activity (change } \\
\text { over time) } \\
\text { 2) In old-age pension } \\
\text { insurance: the gap between } \\
\text { the retirement age and the } \\
\text { duration of a healthy life }\end{array}$ \\
\hline $\begin{array}{l}\text { Individual benefit adequacy: } \\
\text { 1) Individual replacement rate } \\
\text { (gross, net; relative to the last } \\
\text { salary, relative to the average } \\
\text { career salary) } \\
\text { 2) Theoretical replacement rates for } \\
\text { different careers (gross, net) }\end{array}$ & $\begin{array}{l}\text { Long-term - conditions: } \\
\text { 1) Demographic dependency } \\
\text { indicator } \\
\text { 2) Economic burden indicator } \\
\text { 3) System load indicator }\end{array}$ & $\begin{array}{l}\text { (change over time) } \\
\text { 3) In old-age pension insurance: } \\
\text { gap between retirement } \\
\text { age and life expectancy at } \\
\text { retirement age (change over } \\
\text { time) } \\
\text { 4) In old-age pension insurance: } \\
\text { the period of receiving the }\end{array}$ \\
\hline $\begin{array}{l}\text { Collective benefit adequacy: } \\
\text { 1) System replacement rate (gross, } \\
\text { net) } \\
\text { 2) Percentage of people receiving } \\
\text { minimum benefits or below the } \\
\text { adopted value (change over time) } \\
\text { 3) Absolute and relative measures } \\
\text { of poverty in different types } \\
\text { of households } \\
\text { 4) At-risk-of-poverty rate in different } \\
\text { types of households } \\
\text { 5) The rate of severe material } \\
\text { deprivation in various types } \\
\text { of households }\end{array}$ & $\begin{array}{l}\text { Long-term - financial sphere: } \\
\text { 1) Long-term balance in } \\
\text { relations to GDP or the } \\
\text { contribution assessment base } \\
\text { (in \%) - contribution gap } \\
\text { 2) Liabilities from retirement and } \\
\text { disability benefits (gross and } \\
\text { net) in relations to GDP in \% } \\
\text { 3) S1 and S2 indicators* }\end{array}$ & $\begin{array}{l}\text { old-age pension (including } \\
\text { gender) } \\
\text { 5) Analysis of the sensitivity } \\
\text { of e.g. the balance of social } \\
\text { security funds expressed } \\
\text { in relation to GDP } \\
\text { (or in absolute numbers) } \\
\text { to changes in individual } \\
\text { demographic and economic } \\
\text { parameters }\end{array}$ \\
\hline
\end{tabular}

* Indicators used by the European Commission in Fiscal Sustainability Reports.

Source: Own study. 
Another area of assessment is related to the postulates of such reform, especially long-term benefits, which will increase the ability to absorb shocks of a demographic nature (an increase in the share of people in the post-working age population in relation to people of working age), economic (economic, financial, fiscal crisis) and of a political nature. In quantitative terms, the monitoring of this resilience is carried out by analysing the sensitivity of, for example, the balance of social security funds expressed in relation to GDP (or in absolute numbers) to changes in individual demographic and economic parameters, in accordance with the assumed scenarios. Changing each parameter by one percentage point shows the strength of its impact on the balance and the possibility of absorbing negative changes in the system's environment. In the qualitative dimension, it is worth emphasizing, for example, that many countries use the so-called automatic balancing mechanisms in social insurance (especially in the part of retirement and disability insurance). These are mechanisms which, under the legal framework, operate automatically, improving the financial situation and solvency of the system and do not require making political decisions ${ }^{22}$. With regard to pensions, the key to both financial sustainability and adequacy of benefits is a better balance between working lives and retirement times. Therefore, one of the tools to increase resilience to demographic change is to automatically raise the retirement age in line with changes over the course of life.

Equality with regard to the amount of benefits is a relatively new and ambiguous area of assessment, especially at the level of operationalisation. J. Ratajczak presented a comprehensive study of the issue of equality, analysing this issue on the example of the Polish pension system ${ }^{23}$. When economists write about equality in the context of benefits, they mean the same benefit in return for the same amount of contributions. Meanwhile, this is only one of the areas of equality that may conflict with equality in other areas (equality of needs, equality of situations, equal opportunities $)^{24}$.

22. C. Vidal-Meliá, M. Boado-Penas, O. Settergren, Automatic Balance Mechanisms in Pay-As-You-Go Pension Systems, "Geneva Papers on Risk and Insurance" 2009, Vol. 34, p. 287-317. https://doi. org/10.1057/gpp.2009.2, access; T. Jedynak, Automatic Balance Mechanisms as instruments of maintaining pension scheme financial sustainability, "Rozprawy Ubezpieczeniowe. Konsument na rynku usług finansowych" 2018, nr 29, p. 66-85.

23. J. Ratajczak, Równość w systemie emerytalnym. Emerytury kobiet i mężczyzn w Polsce, Poznań, Wydawnictwo Uniwersytetu Ekonomicznego w Poznaniu, 2019.

24. Ibidem. 


\section{Assessment areas in need of strengthening in the context of an aging population}

From the author's perspective, it is necessary to take actions that will make the assessment of the social security system more realistic in terms of the affordability in the financial sense, the acceptability of the redistribution scale and transparency. Such a need arises especially in relation to the social insurance system in Poland.

The assessment of the possibility of maintaining the social insurance system should be considered both from the point of view of labour costs (rate of contributions) and the reconciliation of maintaining the system without interfering with other important social goals. In the area of public policies, almost everything is a matter of choice and prioritization. In the context of a dynamic aging of the population, it is necessary to take into account the interests of all generations to an equal extent. Meanwhile, many changes to the social security system or other social programs (financed from public funds) are introduced without analysing the long-term effects and the distribution of their costs over the next generations. The same can be said about the awareness of the scale of redistribution in the social security system. Redistribution in social insurance systems always occurs (in the individual dimension, within and between generations), while its intensity depends on many factors. Nor is it easy to operationalize and measure redistributive effects. J. Rutecka presented an extensive study on redistribution in the Polish pension system ${ }^{25}$. Intra-generational redistribution occurs between people born in a similar period, e.g. redistribution from men to women due to the use of universal life tables, subsidies to minimum pensions, while intergenerational redistribution occurs when the capitalized value of paid contributions does not correspond to the value of retirement benefits ${ }^{26}$. The scale of redistribution, especially in pension insurance, should be communicated to the public. It is not easy to measure the scale of redistribution, especially in a way that is understandable to society. Nevertheless, in the literature on the subject, you can find interesting proposals also in the dimension of the message. Chybalski proposes an indicator of redistribution symptoms based on the indicator of income inequality. If the ratio of the S80/S20 measure in the 65-population to the S80/S20 measure in the

25. J. Rutecka, Zakres redystrybucji dochodowej w ubezpieczeniowym systemie emerytalnym, Warszawa, Oficyna Wydawnicza SGH, 2012.

26. F. Chybalski, Pomiar redystrybucji $w$ międzynarodowych analizach systemów emerytalnych [in:] Wspótczesne problemy systemów emerytalnych. Wybrane zagadnienia, ed. F. Chybalski i E. Marcinkiewicz, Monografie Politechniki Łódzkiej, Łódź 2015, p. 20. 
$65+$ population is greater than 1 , this means that there is a redistribution in the pension system, because in the retired population the income disparity is lower than in the economically active population ${ }^{27}$. Despite the limitations mentioned by the author of the Redistribution Symptom Index, it seems to be an interesting example of measurement to consider.

Transparency in the field of social security should be an element of the fiscal transparency assessment. These issues have been raised in the literature for years, and they gained practical significance at the beginning of the 21 st century. Proposals for various measures of transparency assessment are proposed, for example, by international organizations such as the International Monetary Fund. "According to Copits and Craig, fiscal transparency is associated with easy access to reliable, comprehensive, timely, understandable, internationally comparable information on government activities, enabling the electorate and financial markets to accurately assess the financial situation of the state and the real benefits and costs of government activities, including their present and future economic and social consequences" 28 . In relation to the social security system, such a role could be played by an independent fiscal council or a domestic actuary, which, incidentally, was to be appointed after the introduction of the pension reform in 1999. However, there are no such authorities in Poland, and the scope and manner of providing information, especially on the future situation of social insurance and the assessment of social and economic effects of the changes introduced, leaves much to be desired.

\section{Summary}

The article analyses the objectives and areas of evaluation of social security systems, with reference to the recommendations of the European Commission and the World Bank for pension security systems. While the assessment of the adequacy and stability of the social security system is well recognized, the issues related to equality, the accepted scale of income redistribution (going beyond the random factor) and the transparency and credibility of information about the social security system are relatively less well understood. In times of dynamic aging of the population, the author considers it necessary to increase the transparency,

27. Ibidem, p. 23.

28. Quote from: E. Malinowska-Misiąg, Wprowadzenie do problematyki jawności i przejrzystości finansów publicznych [in:] Jawność i przejrzystość finansów publicznych, ed. E. Malinowska-Misiąg, Warszawa, Oficyna Wydawnicza SGH, 2017, p. 11. 
comprehensibility and transparency of information about the degree of achievement of goals, their possible modifications and effects on the functioning of social security systems, as well as social and economic effects in the long term. Due to permanent demographic changes, the working generation (covered by social insurance) should be informed about the scale of redistribution carried out by the social insurance system, about the financial consequences of proposed or introduced changes in social insurance systems, taking into account the appropriate time horizon. It seems that an effective and credible message regarding the social security situation should be delivered by an independent institution. With the introduction of the social insurance reform in Poland in 1999, it was proposed to create the Office of the National Actuary, but this office was not established. Membership in the European Union should oblige us to establish an independent fiscal council, but there is no such body either. The lack of independent bodies hinders communication and access to reliable information about the expected situation of social insurance in the future. The reliability of the information allows you to build trust in the system. Without trust, the achievement of social security goals could be jeopardised.

\section{Bibliography}

Barr N., Diamond P., Economics of pensions, “Oxford Review of Economic Policy” 2006, Vol. 22 (1).

Barr N., Państwo dobrobytu jako skarbonka. Informacja, ryzyko, niepewność a rola państwa, Warszawa, Wydawnictwo Wyższej Szkoły Pedagogicznej TWP w Warszawie, 2010.

Bednarczyk T.H., Bielawska K., Jackowska B. et al., Ekonomiczne i demograficzne uwarunkowania funkcjonowania i rozwoju ubezpieczeń, Gdańsk, Wydawnictwo Uniwersytetu Gdańskiego, 2019.

Bielawska K., Rejmer A., Zakres wykorzystania bazy ekonomicznej ubezpieczenia społecznego określany przez przepływy środków pieniężnych [in:] Baza ekonomiczna ubezpieczenia społecznego, ed. R. Pacud, Warszawa, Difin, 2019.

Bielawska K., Adekwatność emerytur w świetle zmian polskiego systemu emerytalnego, "Zarządzanie i Finanse" 2016, nr 4 (14).

Chybalski F., Adekwatność dochodowa [in:] Adekwatność dochodowa, efektywność i redystrybucja w systemach emerytalnych. Ujęcie teoretyczne, metodyczne i empiryczne, ed. F. Chybalski, Warszawa, Wydawnictwo C.H. Beck, 2016.

Chybalski F., Marcinkiewicz E., The Replacement Rate: An Imperfect Indicator of Pension Adequacy in Cross-Country Analysis, "Social Indicators Research" 2015, No. 1. 


\section{Monitoring and assessment of social security systems}

Chybalski F., Pomiar redystrybucji w międzynarodowych analizach systemów emerytalnych [in:] Współczesne problemy systemów emerytalnych. Wybrane zagadnienia, ed. F. Chybalski i E. Marcinkiewicz, Monografie Politechniki Łódzkiej, Łódź 2015.

Chybalski F., Skuteczność i efektywność systemu emerytalnego. Koncepcja analizy i próba pomiaru, Łódź, Wydawnictwo Politechniki Łódzkiej, 2012.

Cole C.R., Liebenberg A.P., An Examination of Retirement Income Adequacy Measures and factors affecting retirement preparedness, https://ssrn.com/abstract $=1272067$, access

Convention No. 102 of the International Labour Organisation on Minimum Standards of Social Security, Journal of Laws 2005 No. 93 pos. 775.

European Commission, The 2018 Ageing Report: Economic and budgetary projections for the 28 EU Member States (2016-2070), Institutional Paper 079, Brussels, 2018, doi:10.2765/615631 (online).

European Commission, Pension Adequacy Report 2018 - Current and future income adequacy in old age in the EU, Brussels 2018.

European Commission, Fiscal Sustainability Report 2018, Institutional Paper 094, Brussels, 2019, doi:10.2765/435292 (online).

European Commission, Adequate and Sustainable Pensions. Joint Report by the Commission and the Council, Luxemburg 2003.

Golinowska S., Polityka społeczna państwa w gospodarce rynkowej. Studium ekonomiczne, Warszawa, Wydawnictwo Naukowe PWN, 1994.

Holzmann R., Hinz R., Dorfman M., Pension Systems and Reform Conceptual Framework, SP Discussion Paper 2008, No. 0824, Washington D.C.

Holzmann R., Hinz R., Old Age Income Support in the 21st Century. An International Perspective on Pension Systems and Reform, Washington, The World Bank, 2005.

Jedynak T., Automatic Balance Mechanisms as instruments of maintaining pension scheme financial sustainability, "Rozprawy Ubezpieczeniowe. Konsument na rynku usług finansowych” 2018, nr 29.

Kawiński M., Ubezpieczenia publiczne i prywatne $w$ polityce społecznej. Skuteczność $i$ efektywność, Warszawa, C.H. Beck, 2011.

Malinowska-Misiąg E., Wprowadzenie do problematyki jawności i przejrzystości finansów publicznych [in:] Jawność i przejrzystość finansów publicznych, ed. E. Malinowska-Misiąg, Warszawa, Oficyna Wydawnicza SGH, 2017.

Ratajczak J., Równość w systemie emerytalnym. Emerytury kobiet i mężczyzn w Polsce, Poznań, Wydawnictwo Uniwersytetu Ekonomicznego w Poznaniu, 2019.

Rutecka J., Zakres redystrybucji dochodowej w ubezpieczeniowym systemie emerytalnym, Warszawa, Oficyna Wydawnicza SGH, 2012.

Szumlicz T., Ubezpieczenie. W sprawie zastrzeżenia terminologicznego, "Wiadomości Ubezpieczeniowe" 2009, nr 1 . 


\section{Monitoring and assessment of social security systems}

Vidal-Meliá C., Boado-Penas M., Settergren O., Automatic Balance Mechanisms in Pay-As-You-Go Pension Systems, "Geneva Papers on Risk and Insurance" 2009, No. 34, https://doi.org/10.1057/ gpp.2009.2, access

Żukowski M., Otwarta koordynacja zabezpieczenia emerytalnego w Unii Europejskiej - nowy etap europejskiej polityki społecznej?, "Polityka społeczna” 2002, nr 11-12. 